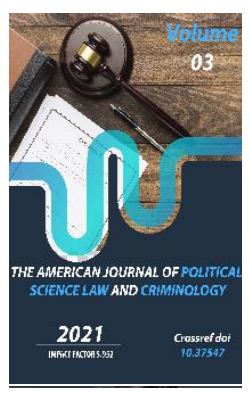

\title{
A Disciplinary Responsibility By The Labor Legislation Of The Republic Of Uzbekistan
}

Mukhammadamin Karimjonov

Lecturer Of Tashkent State University Of Law, Uzbekistan

\section{ABSTRACT}

The article is dedicated to the study of legal regulation of the institution of disciplinary responsibility and identify its main problems. The expediency of separation of general and special disciplinary responsibility is substantiated. The article analyzes disciplinary responsibility as a type of judicial responsibility, concept of labor discipline, disciplinary offense, systematic and a single flagrant violation by the worker of his labor duties, peculiarities of the application of disciplinary sanctions.

There were developed both theoretical proposals and proposals for amending legislation on the legal regulation of disciplinary responsibility.

\section{KEYWORDS}

Judicial responsibility, disciplinary responsibility, the discipline of labor, labor order, disciplinary sanction, reprimand, fine, termination of the labor contract, systematic and a single flagrant violation.

\section{INTRODUCTION}

Disciplinary responsibility represents a form of judicial responsibility specific to the labor law, containing the ensemble of the legal norms that define disciplinary deviations, establish the sanctions and regulate the background and procedural conditions for their application. 
Being specific to the work relation, the disciplinary responsibility occurs whenever an employee violates the obligation to respect labor discipline. This type of responsibility has a contractual nature, a strictly personal character, exercising sanctioning, preventive and educational functions.

In accordance with the Constitution of the Republic of Uzbekistan, everyone shall have the right to work, including the right to choose their occupation. Every citizen shall be entitled to fair conditions of labor and protection against unemployment in accordance with the procedure prescribed by law. Any forced labor shall be prohibited, except as punishment under the sentence of a court, or in some other instances specified by law.

As noted by the Director-General of the International labor organization Guy Ryder fundamental and large-scale changes are being implemented in Uzbekistan, which has significantly improved the country's positive image in the eyes of the world community, contribute to improving the standard of living of the population, provide employment and decent working conditions for citizens of Uzbekistan [1].

Labor law is one of the independent branches of the unified law of the Republic of Uzbekistan. Like any independent branch of law, it has a certain subject of regulation of social relations and the corresponding method of legal impact on these relations. Despite its independence, labor law also has common features that are characteristic of any other industry. The unity of the general and the particular is inherent in it. Any branch of law includes norms that provide for responsibility for violation of the prohibitions and instructions defined by these norms. These norms form the legal institution of legal responsibility, which is a generalizing principle. Legal responsibility acting as an independent institution of law, is one of the forms of social responsibility.

\section{MATERIALS AND METHODS}

In the course of the research, such methods as comparative legal, systemic and structural, logical, sociological, complex study of scientific sources, induction and deduction, empirical research data were applied.

\section{RESULT AND DISCUSSION}

Disciplinary responsibility of employees, as an independent type of legal responsibility, occurs for violation of labor discipline, that is, an illegal violation of the employee's work duties assigned to him (violation of internal labor regulations, job descriptions, regulations, orders of the head, technical rules, etc.). Such an offense is called a disciplinary offense.

Labor legislation distinguishes between two types of disciplinary responsibility: general and special.

General disciplinary responsibility is regulated by the Labor Code of the Republic of Uzbekistan (in the next places - Labor Code) and applies to all employees who have entered into an employment contract, except for those for whom special disciplinary responsibility has been established.

The implementation of general disciplinary responsibility is carried out in accordance with the procedure regulated by the Labor Code, which provides for a number of legal 
guarantees for employees in order to prevent unreasonable prosecution of them.

Special disciplinary responsibility is governed by other laws and discipline statutes and regulations.

Special disciplinary responsibility implies a broader concept of disciplinary offense and provides for a number of additional penalties. The establishment of special disciplinary responsibility is conditioned, firstly, by the specifics of the labor functions performed by these workers, and, secondly, by the especially grave consequences that may occur as a result of non-fulfillment or improper fulfillment of their labor duties assigned to them.

Disciplinary responsibility of certain categories of civil servants (investigative and prosecutorial, judicial and a number of other bodies) is regulated by special acts of the Republic of Uzbekistan

Disciplinary responsibility as a type of legal responsibility should be distinguished from responsibility provided for by the rules of administrative law. They differ in the nature of the offenses for which this or that responsibility comes, according to the subjects who have the right to impose penalties, according to the circle of persons who can be brought to justice, as well as the types of penalties applied to them.

Unlike disciplinary liability, which, as already noted, occurs for violation of labor discipline (disciplinary offense), administrative responsibility occurs for committing an administrative offense, i.e. illegal, guilty action (inaction) of an individual or legal entity, for which the Code of the Republic of Uzbekistan on Administrative Responsibility. For example, for violation of fire safety rules, traffic rules, etc.

Disciplinary responsibility should be understood as the application by the head of the enterprise against the employee guilty of the disciplinary offense of the measures of punishment provided for in the legislative and local acts.

The prerequisites for the occurrence of an employee's disciplinary responsibility are:

A) The commission by an employee who is in labor legal relations with the employer of a guilty act or omission;

B) Unlawfulness (but not socially dangerous) of the act committed by the employee;

C) The obviousness of the onset of material or moral harm.

When bringing an employee to disciplinary responsibility, the observance of legality and social justice, expediency, inevitability of punishments and guarantees to the employee must be ensured [2].

The basis for bringing an employee to disciplinary responsibility is the commission of a disciplinary offense by the employee.

A disciplinary offense is understood as a guilty unlawful failure or improper performance by an employee of his job duties (violation of job duties).

It is not allowed to bring an employee to disciplinary liability if non-performance or improper performance their work duties took place for reasons beyond the control of from the employee (failure by the employer to provide the conditions necessary for the 
employee to fulfill his job duties, force majeure circumstances).

Disciplinary penalties are imposed only by the employer with whom the employee has an employment relationship. Administrative penalties have the right to be applied by specially authorized bodies or persons with whom the offender is not associated with labor relations (for example, the state labor inspectorate, the police, etc.).

Thus, disciplinary responsibility arises for the commission of a disciplinary offense by an employee.

A disciplinary offense is characterized by the fact that it is expressed in the unlawful and guilty failure of the employee to perform his job duties.

The employee's fault for committing a disciplinary offense and his unlawfulness are prerequisites for bringing to disciplinary responsibility. Moreover, both of these conditions must be present at the same time, i.e. their combination is necessary.

According to the academic lawyer M.Y.Gasanov "You should pay attention to the fact that in cases stipulated by legislation, local acts of an enterprise or an employment contract, regular professional development is the responsibility of the employee.

Accordingly, the refusal of an employee, without good reason, to undergo advanced training within the established timeframe is a violation by the employee of his job duties and may serve as a basis for bringing him to disciplinary responsibility" [3].
Labor discipline is the binding and organizing force without which collective work and the achievement of collective results is unthinkable. Due to labor discipline, a special regime is provided, which is so necessary for the joint, coordinated work of numerous employees.

The content of labor discipline includes the mutual obligations of the employee and the employer must faithfully and accurately perform their duties. Labor discipline is ensured by the creation of the necessary organizational and economic conditions for normal work by means of incentives and rewards for conscientious work, by applying penalties to unscrupulous workers.

Bringing an employee to disciplinary responsibility is allowed only in compliance with the procedure established by law. At the same time, the employer has the right to apply to the employee only those disciplinary measures that are provided for by law.

A worker shall be obliged in good faith to fulfill his labor duties, comply with labor discipline, execution legal regulations of the employer in a timely way and precisely, comply with technological discipline, requirements relating to the protection of labor, technical safety, and production sanitation, and treat with care the property of the employer.

Labor duties of a worker shall be clarified in the rules of internal labor order, charters and statutes on discipline, local acts applicable in the enterprise (collective contracts, instructions, and so forth), and the labor contract.

For committing a disciplinary offense, the employer has the right to apply one of the 
disciplinary sanctions to the employee, provided for by the Labor Code. Disciplinary sanctions can be applied for the violation, i.e. guilty unlawful failure or improper performance by the employee of his / her job duties (violation of internal regulations, job descriptions, provisions of legal orders of the employer, technical rules, etc.).

Therefore, it cannot be considered a violation of labor obligations and cannot serve as a basis for the application of disciplinary sanctions, in particular, the employee's refusal to perform work to which he was illegally transferred, to continue working in new working conditions, to fulfill the employer's order on an issue that, in accordance with legislative and other normative acts on labor can be resolved only with the consent of the employee (the employee's refusal to fulfill the employer's requirement to withdraw from vacation or to postpone the vacation for another period, from engaging in overtime work, refusal of a pregnant woman or a woman with children under the age of fourteen years old (disabled children - up to sixteen years old) from work at night, on weekends, from being sent on a business trip, refusal of a disabled person to work at night or on weekends, etc.)

On the basis of Article 181 of the Labor Code, for a violation of labor discipline an employer shall have the right to apply the following measures of disciplinary sanction to a worker:

1) Reprimand;

2) Fine in an amount of not less than $30 \%$ of average monthly earnings.

Instances of the imposition of a fine on a worker in an amount of not more than
$50 \%$ of average monthly earnings may be provided for by the rules of internal labor order;

3) Termination of the labor contract (Article 100, paragraph two, points 3 and 4).

The application of measures of disciplinary sanction not provided for by the present Article shall be prohibited [4].

The termination of the employment contract under paragraphs. 3 or 4 parts of the second points of article 100 of the Labor Code is a disciplinary sanction, notification of an employee and termination of labor relations with him on these grounds is allowed only within the time limits established for the imposition of disciplinary sanctions.

As the academic lawyer M.Y. Gasanov notes, "It is important to note that the list of disciplinary sanctions has been brought in line with international legal acts and market requirements, in contrast to the previously existing Labor Code. In particular, as contradicting the ILO Convention №. 105 of 1957. "On the abolition of forced labor" was excluded from the Labor Code of the Republic of Uzbekistan such a disciplinary measure as transfer to a lower-paid job [5].

Disciplinary sanctions shall be applied by the persons (or agencies) to whom the right to hire has been granted.

A written explanation must be demanded by the worker before the application of a disciplinary sanction. A refusal of the worker to give an explanation may not serve as an obstacle to the application of the sanction for an offense previously committed by him. 
When applying a disciplinary sanction, the gravity of the offense committed, the circumstances of its commission, and the previous work and behavior of the worker shall be taken into account.

Only one disciplinary sanction may be applied for each offense.

A disciplinary sanction shall apply directly to the discovery of an offense, but not later than one month from the date of its discovery, not counting the time of illness of the worker or his sojourn on leave.

Recovery may not be applied later than six months from the date of commission of the offense, and with regard to the results of the audit or verification of financial-economic activity, later than two years from the date of its commission. The time of the proceedings with regard to the criminal case shall not be included in the said periods.

The order (or regulation) or decree concerning the application of a disciplinary sanction shall be announced to the worker under receipt.

The period of operation of a disciplinary sanction may not exceed one year from the date of its application. If within this period a worker is not subjected to a new disciplinary sanction, he shall be considered as not having a disciplinary sanction.

An employer who has applied a disciplinary sanction shall have the right to cancel it before the expiry of the year at own initiative, at the request of the worker, at the petition of the labor collective, or of the immediate superior of the worker.
A disciplinary sanction may be appealed in the procedure established for the consideration of individual labor disputes.

The agency considering the labor dispute shall have the right, taking into account the circumstances under which the offense was committed, the previous behavior of the worker, attitude towards labor, conformity of the disciplinary sanction to the gravity of the offense committed, and compliance by the employer with the procedure for the imposition of the sanction, to deem the application of the disciplinary sanction to the worker to be illegal and to render a decision concerning the vacating thereof.

\section{ACKNOWLEDGEMENTS.}

Labor law provides additional guarantees for certain categories of employees, and there are some exceptions to the application of disciplinary sanctions to this category of persons.

A) The imposition of disciplinary sanctions, termination of the labor contract at the initiative of the employer with workers elected to representative organs and not relieved from production work, and also the termination of labor relations at the initiative of the employer with the workers elected to the representative organs within two years after the end of their elective powers, shall not be permitted without the preliminary consent of the local agency for labor (Article 25 of the Labor Code).

B) The termination of a labor contract with pregnant women and women having children up to three years of age at the initiative of the employer shall not be 
permitted except for instances of the full liquidation of the enterprise (Article 237 of the Labor Code).

C) Termination of the labor contract with workers younger than eighteen years of age at the initiative of the employer shall be permitted, in addition to compliance with the general procedure for termination of a labor contract, with the consent of the local agency for labor (Article 246 of the Labor Code).

D) There are specifics in the labor legislation in the application of disciplinary sanctions against the head of the enterprise. The employment contract concluded between the owner of the enterprise and the head of the enterprise may establish a list of single flagrant violations of labor duties that may lead to the termination of the employment contract.

Also during the coronavirus pandemic, there were some temporary restrictions were imposed on the use of disciplinary sanctions [6].

According to Decree of the President of the Republic of Uzbekistan of March 19, 2020 № 5969 "On priority measures to mitigate the negative impact on the branches of the economy of the coronavirus pandemic and global crisis events" prohibited to terminate an employment contract with an employee who is infected with a coronavirus infection or placed in quarantine, as well as those who are the parent (substitute, guardian, or trustee) of a child under the age of 14 years, at the initiative of the employer.

That is, it is clear from this norm that employers can not terminate labor contract with with an employee who is infected with a coronavirus infection or placed in quarantine, as well as those who are parent (substitute, guardian, or trustee) of a child under the age of 14 years even if they systematic or a single flagrant violate their labor duties.

In practice, there are cases when an employee with whom an employment contract was concluded does not start work within the time period stipulated in the contract. In accordance with the current legislation, if the employee did not start work without a valid reason, the employer has the right to apply disciplinary measures to him, including terminating the employment contract with the employee in accordance with the established procedure under paragraph 4 of part two of Article 100 of the Labor Code. In order to apply a disciplinary sanction to an employee, the employer must request an explanation from him. However, it is often impossible to do this, since an employee who does not appear for work has left for another locality, or for other reasons is absent from his place of permanent residence.

\section{DECISSION}

In connection with the above, it seems appropriate to take into account the experience of the Russian Federation (part four of article 61 of the Labor Code) and fix in the Labor Code a norm that provides that if an employee does not start work on time without a valid reason within seven days, the employment contract is canceled.

Expand the list of disciplinary sanctions. For example, it is advisable to take into account the norms of the labor legislation of the CIS countries, such as Turkmenistan (clause 1 of article 164 of the Labor (ode), Kazakhstan (clause 1 of article 64 of the Labor Code), 
Kyrgyzstan (article 146 of the Labor Code), Armenia (article 223 of the Labor Code), Tajikistan (Article 62 of the Labor Code), Belarus (Article 198 of the Labor Code) which lists the types of disciplinary sanctions that are absent in our labor legislation (namely, only three types of disciplinary sanctions are indicated, including a reprimand, a fine, and termination of an employment contract).

In our opinion, taking into account the experience of the above countries, to include in the list of disciplinary sanctions provided for in Part 1 of Article 181 of the Labor Code, such types of penalties a severe reprimand, transfer to a lower position, and thereby expand and develop this norm of the Labor Code of the Republic of Uzbekistan.

To summarize, labor discipline is the hallmark of labor relations. The duty to observe labor discipline is one of the main responsibilities of an employee as a subject. Compliance with labor discipline, a proper performance by an employee of labor duties and prevention of their misconduct are the most important factors in the growth of production and the competitiveness of the employer in the economic sphere. Many Uzbek scientists in the field of labor law have addressed the problems of the institution of disciplinary responsibility in their research.

In recent years, issues of disciplinary responsibility have been actively developed in the works of Ismailov, Sh.A [7], Burxanxodjayeva, X.V [8], Raximov, M.A [9], Raximberganova, B.D [10], Xojabekov, M.J [11], Rahimqulova, L.U. [12].

As noted by the President of the Republic of Uzbekistan Shavkat Mirziyoyev in the address to Oliy Majlis, we all know that reform means renovation, change. In order for the reforms to succeed, first of all, our leaders and people need to change. When a person changes, society changes. To achieve this goal, it is vital that today leaders of all levels, members of the parliament and local legislative bodies need to organize their work on the basis of critical analysis, rigorous discipline and personal responsibility [13].

Disciplinary responsibility has an important role in the regulation of labor relations, allowing the employer to achieve the effective fulfillment of labor duties by the employee. The disciplinary sanctions and the grounds for their application help to protect the employee from the arbitrariness of the employer and, at the same time, achieve a positive effect from the employee's performance of his labor duties.

\section{REFERENCES}

1. https://www.un.int/uzbekistan/news/preside nt-republic-uzbekistan-receives-directorgeneral-international-labor-organization

2. Турсунов Й. Трудовое право. Учебник. Т.: Издательство ТГЮИ. 2004 г. -252 стр

3. Гасанов М. Трудовое право Республики Узбекистан. Общая часть. T. «LESSON PRESS», 2016.C.86.

4. Labor Code of the Republic of Uzbekistan. Translated, with an Introduction, by William E. Butler, Professor of Comparative Law in the University of London, $\odot 2005$ by William Elliott Butler.

5. М.Ю.Гасанов. Трудовой кодекс: Развитие инициативы работника и работодателя. Народное слово. 18 ноября 1995г. С. 2. 
6. Karimjonov.M.M. (2020) "Peculiarities of application of disciplinary sanctions to individual categories of workers under quarantine," Review of law sciences: Vol. Special, Available at: https://cyberleninka.ru/article/n/osobennosti -primeneniya-distsiplinarnyh-vzyskaniy-votnoshenii-otdelnyh-kategoriy-rabotnikov-vusloviyah-karantina/viewer

7. Ismailov, Sh.A. (2018) "Problems of legal regulation of differentiation in the labor sphere," Review of law sciences: Vol. 2 : Iss. 1 , Article $14 . \quad$ Available at: https://uzjournals.edu.uz/rev_law/vol2/iss1/14

8. Burxanxodjayeva, X.V. (2020) "Features of regulation of labor relations in microfirms," Journal of Law Research: Vol. 8: Available at: https://law.tadqiqot.uz/index.php/law/article /view/144

9. Raximov, M.A. (2018) "New institution: resolving labor disputes through mediation," Review of law sciences: Vol. 3 : Iss. 1 , Article 11. Available at: https://uzjournals.edu.uz/rev_law/vol3/iss1/11

10. Raximberganova, B.D. (2018) "The issues of improving the basics of working on situations beyond the will of the parties," Review of law sciences: Vol. 2 , Article 15. Available at: https://uzjournals.edu.uz/rev_law/vol2/iss1/15

11. Khojabekov, M.J. (2020) "Employment rights and privileges of persons with disabilities", TSUL Legal Report International electronic scientific journal, 1(1). Available at: https://legalreport.tsul.uz/index.php/journal/ article/view/12

12. Rahimqulova, L.U. (2020) "Subjects of labor disputes," Journal of Law Research: Vol. 8 :
Available

at: https://law.tadqiqot.uz/index.php/law/article /view/105/106

13. https://www.un.int/uzbekistan/news/address -president-republic-uzbekistan-shavkatmirziyoyev-oliy-majlis 